\title{
A cidadania sob o signo do desvio: Para uma crítica da "tese de excepcionalidade brasileira" ${ }^{1}$
}

Sergio B. F. Tavolaro ${ }^{2}$

e Lília G. M. Tavolaro 3

Resumo: O propósito central do artigo consiste em realizar uma consideração crítica do que denominamos de "tese da excepcionalidade normativa brasileira". As duas principais questões orientadoras são: em primeiro lugar, haveria alguma desvantagem, do ponto de vista analítico, em manterse orientado pela noção conforme a qual a experiência da cidadania no Brasil é algo particular em relação ao "centro da modernidade"? Em segundo lugar, é possível vislumbrar outra maneira profícua de refletir a respeito da experiência da cidadania no Brasil para além da "tese da excepcionalidade normativa"?

Palavras-chave: cidadania no Brasil, pensamento social brasileiro, modernidade.

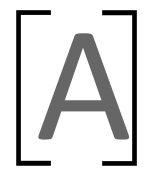

tentemos para a existência de uma poderosa tese que permeia nossa sociologia política contemporânea a respeito da experiência da cidadania no Brasil. De acordo com ela, tal experiência foi e permanece marcada por traços que a tornam peculiar em relação àquela dos chamados "países modernos centrais". Essa "tese da excepcionalidade normativa brasileira" - assim denominada por razões que explicitaremos ao longo deste trabalho - de forma alguma pode ser acusada de passageira ou estranha às nossas tradições intelectuais: por um lado, ela acha-se ancorada em referências teóricas e interpretativas sólidas tanto no seio do pensamento sociológico internacional quanto entre os principais intérpretes da sociedade brasileira. Notavelmente, tal tese atravessa perspectivas analíticas distintas, abordagens diversas, em diferentes momentos do pensamento social brasileiro. Essa condição contribui sobremaneira para que ela goze de ampla legitimidade no campo acadêmico além de auxiliá-la a renovar sua posição privilegiada no debate científico, a ponto de torná-la pedra de toque para novas reflexões teóricas e investigações com ênfase propriamente empírica. Por outro lado, há também de se reconhecer que sua força
1. O presente artigo almeja avançar algumas das ideias lançadas mas não plenamente desdobradas em Tavolaro (2008) e Tavolaro (2009). Os autores agradecem os organizadores e debatedores do GT

"Para onde vai a

Teoria social contemporânea?", Anpocs, 2009, onde o trabalho foi originariamente apresentado e discutido.

2. Sergio B. F.

Tavolaro é professor adjunto do Departamento de Sociologia da UnB. Doutor em sociologia pela The New School for Social Research.

3. Lília G. M. Tavolaro é professora adjunta do Departamento de Ciências Sociais da Universidade Federal de Uberlândia. Doutora em sociologia pela The New School for Social Research. 
e prestígio decorrem do fato de suas reivindicações de verdade ampararem-se em evidências empíricas bastante consistentes: configurações de direitos e deveres diversos que coloriram momentos distintos da história brasileira são resgatadas, elencadas e acentuadas, de maneira convincente, como provas da suposta peculiaridade normativa que nos diferenciaria do "núcleo da modernidade".

Diante desse quadro, são duas as questões gerais que articulam o presente trabalho: em primeiro lugar, haveria alguma desvantagem, do ponto de vista analítico, em manter-se orientado por essa noção de que a experiência da cidadania no Brasil é, sim, algo particular em relação ao "centro"? Em segundo lugar, é possível vislumbrar outra maneira profícua de refletir a respeito da experiência da cidadania no Brasil para além da "tese da excepcionalidade normativa"? O propósito central de nosso trabalho consiste em realizar uma consideração crítica dessa tese e de suas implicações analíticas.

Em vista desses objetivos, a primeira tarefa que julgamos fundamental consiste em mapear, ao menos minimamente, o campo discursivo do pensamento social brasileiro no interior do qual a referida tese deita suas raízes e a partir do qual se projeta como referência primordial às investigações a respeito da experiência da cidadania no Brasil. A segunda tarefa que nos parece essencial é identificar a maneira como tal tese é codificada no campo da sociologia política devotada ao estudo da cidadania na modernidade. O terceiro desafio consiste em lançar mão de eventuais evidências empíricas que, ao acentuarem os pontos cegos da "tese da excepcionalidade", justificariam a exploração de uma alternativa explicativo-interpretativa. Por fim, colocamo-nos como um último desafio dialogar com a teoria sociológica contemporânea a fim de indicar uma maneira alternativa de iluminar os aspectos da dinâmica e configuração sociais que mais nos interessam no presente trabalho - isto é, a construção e vivência da cidadania moderna no Brasil.

1. Uma "regularidade na dispersão":

O pensamento social brasileiro e a nossa singularidade societal

Todos sabemos que há, no seio do pensamento social brasileiro, um grande número de "linhagens" ou "famílias intelectuais" a partir das quais a experiência societal brasileira é tentativamente interpretada e explicada (Brandão, 2007). Cabe reconhecer que várias dessas "linhagens" revelam-se pouco 
compatíveis ou, no limite, mutuamente excludentes, apoiando-se em aspectos díspares por meio dos quais se busca jogar luz sobre nossa "especificidade moderna": clima, cabedal cultural, herança histórica, arcabouço institucional, vulnerabilidade econômica são apenas algumas das diversas âncoras desses esforços explicativos e interpretativos da experiência da modernidade no Brasil. Daí, muitas vezes, o argumento segundo o qual os riscos de grandes generalizações a respeito do pensamento social brasileiro sobrepujam em muito as eventuais vantagens. Na contramão desse argumento, gostaríamos de explorar a hipótese da existência de uma dada ideia-força que atravessaria muitas dessas "linhagens", a despeito de suas irredutíveis particularidades, e que toma como ponto de partida a existência de uma singularidade brasileira em relação ao chamado "núcleo dinâmico da modernidade". Entendemos que, apesar de verdadeiramente multifacetado, esse campo discursivo mostra-se circunscrito e permeado pela noção segundo a qual a "peculiaridade" da sociedade brasileira pós-tradicional é um fato consumado, um fait accompli a ser explicado e compreendido. A importância de resgatar alguns elementos nodais desse campo discursivo deve-se, a nosso ver, ao fato de que é nele que a "tese da excepcionalidade" - que orienta parte majoritária das investigações a respeito da experiência da cidadania no Brasil - tem sua principal morada e de onde retira parcela substantiva de sua legitimidade no debate científico. ${ }^{4}$

Ao menos desde o final do século XIX, momento imediatamente anterior ao início da institucionalização da sociologia na academia brasileira, essa ideia-força começou a ganhar contornos mais claros. Em O abolicionismo, preocupado que estava em mostrar como a escravidão era a causa maior de nossas mazelas sociais, Joaquim Nabuco já argumentava tratar-se de uma "instituição fóssil", que só existia "em nosso período social numa porção retardatária do globo, que escapa por infelicidade sua à coesão global" (Nabuco, 2000: 79, grifos nossos). Para Nabuco, essa singularidade brasileira, expressa de maneira determinante pela manutenção tardia da escravidão, seria indicativa de nosso atraso e de nossa "decadência prematura" (Nabuco, 2000: 113). A resistência de conferir aos negros o status de cidadãos plenos seria, para Nabuco, a prova de que a ordem legal no Brasil caminhava na contramão do que chama de "princípios fundamentais do direito moderno", que são a "base das sociedades civilizadas, e cuja violação em uma importa uma ofensa a todas as outras" (Nabuco, 2000: 79).

Ainda no último quartel do século XIX, a "peculiaridade de nosso meio" teve peso determinante na maneira como Silvio Romero e muitos de seus
4. Cabe a

advertência, porém, de não ser nossa intenção realizar um exercício

sistemático, minucioso e exaustivo de reconstrução desse campo. Trata-se apenas e tãosomente de identificar nessa "dispersão discursiva" (isto é, as várias abordagens e perspectivas no interior do pensamento social brasileiro, propriamente dito) uma certa

"regularidade" (qual seja, a ideia-força de nossa suposta singularidade societal), que tem se revelado capaz, como nenhuma outra ideia, de orientar a pesquisa e a reflexão acerca da normatividade do Brasil póstradicional. Conforme sabemos, para Foucault (1972), a regularidade $n a$ dispersão é um dos aspectos centrais de toda formação discursiva. 
contemporâneos da "Escola de Recife" explicavam a aclamada "peculiaridade brasileira" (Chacon, 2008): a natureza seria, nesse sentido, "uma das faces mais distintas de nosso país" (Romero, 2001: 28). Não por acaso, a raça também se apresentava como outro aspecto fundamental a nos diferenciar dos países mais desenvolvidos. Mas talvez fosse a força das "influências estrangeiras" o maior sinal de nosso atraso: no Brasil, "os germes e, digamos assim, os modelos, as formas do pensamento cultural vêm de fora, vêm da Europa e dos Estados Unidos" (Romero, 2001: 61). Para Romero, isso não significava que nossas referências linguísticas, religiosas, legais, artísticas e literárias não fossem aquelas mesmas da moderna cultura ocidental. No entanto, "essa contribuição imensa com que entraram para a formação da psique nacional se viu, desde os primórdios, ir modificando, pela ação do meio e pelo cruzamento com os índios e com os africanos" (Romero, 2001: 46-47). Tudo isso ajudaria a explicar inclusive "nossa falta de ousadia para os grandes empreendimentos industriais e outros quaisquer" (Romero, 2001: 46).

Já no início do século XX, Alberto Torres mostrou-se ainda mais convicto em relação à existência de uma distância abissal entre a ordem normativa idealizada pelas elites brasileiras e o despreparo da sociedade mais ampla para levá-la a termo. Em suas reflexões a respeito da ordem política e constitucional que se seguiu à proclamação da república, Torres avaliava que "a nossa lei fundamental não é uma 'constituição'; é um estatuto doutrinário, composto de transplantações jurídicas alheias" (Torres, 1938: 85). O problema maior era que, conforme o autor, essas normas jurídicas não encontravam lastro em nossa realidade: "o nosso povo conta uma imensa massa de analfabetos e, sem incluir os indigentes, de indivíduos ainda em estado, material e moral, de selvageria" (Torres, 1938: 102). O padrão de funcionamento dos partidos políticos no Brasil seria a prova cabal de que os princípios normativos da democracia liberal não teriam qualquer conexão com a nossa sociedade: "eles não passam de agrupamentos adventícios, que servem menos para congregar opiniões, do que para estreitar solidariedades pessoais e embaraçar iniciativas livres" (Torres, 1938: 100). Naquele mesmo período, Oliveira Vianna admitia a existência de "pontos numerosos de semelhança entre o nosso grupo nacional e os outros grupos nacionais do mundo civilizado". Contudo, a despeito dessas afinidades, "somos diversos por muitos aspectos, distintos por muitos lados, peculiares e exclusivamente nós mesmos por muitos modos de ser e de existir" (Vianna, 1956: 40). Tendo sido, desde o início, um povo de agricultores e pastores, organizado a princípio em grandes latifúndios com vida própria, sob a ação de um 
ambiente natural bastante diverso do europeu, as instituições que floresceram no velho continente cá não encontraram nenhum respaldo. Ante a resistência da sociedade rural (marcada pela dispersão territorial e pela coesão em torno do "clã fazendeiro") para ceder espaço às instituições públicas, o Estado brasileiro viu-se impelido a centralizar poder de maneira demasiada a fim de lograr construir a sociedade nacional. Não poderíamos, nesse sentido, ser mais distintos dos povos anglo-saxões: enquanto os ingleses criaram garantias liberais para protegerem-se da realeza, "o nosso povo não batalhou nunca por elas"; assim, "entre nós, essas belas franquezas e garantias liberais são apenas conquistas literárias de uma minoria aristocrática de oradores, publicistas e pensadores" (Vianna, 1987: 255).

Os anos 1930, início da institucionalização das ciências sociais no Brasil, testemunharam a publicação de três obras cujos autores se tornariam referências centrais à "tese da excepcionalidade brasileira". Casa-grande \& senzala, Raízes do Brasil e Evolução política do Brasil lograram, sim, dar um novo tom às interpretações da sociedade brasileira. Ainda assim, Gilberto Freyre, Sergio Buarque de Holanda e Caio Prado Jr. em hipótese alguma escaparam ao pressuposto da "singularidade societal brasileira". Sergio Buarque, vale lembrar, praticamente abre sua interpretação clássica com a célebre advertência:

Trazendo de países distantes nossas formas de convívio, nossas instituições, nossas idéias, e timbrando em manter tudo isso em ambiente muitas vezes desfavorável e hostil, somos ainda hoje uns desterrados em nossa terra (Holanda, 1994: 3).

Nossa herança cultural luso-ibérica, nosso passado rural, o personalismo e o paternalismo que tanto nos distinguiam de "terras protestantes", o peso exagerado das relações familiais, nossa "aversão congênita" à organização racional da vida social, tudo contribuía negativamente para que a democracia no Brasil jamais deixasse de ter sido "um mal-entendido". Afinal de contas, "uma aristocracia rural e semifeudal importou-a e tratou de acomodála, onde fosse possível, aos seus direitos ou privilégios, os mesmos privilégios que haviam sido, no Velho Mundo, o alvo da luta da burguesia contra os aristocratas" (Holanda, 1994 p. 119). Freyre, igualmente, não deixa qualquer dúvida quanto à singularidade daquela que para ele foi a primeira civilização a se constituir nos trópicos.

Híbrida desde o início - segundo o autor -, a formação brasileira tem sido [...] um processo de equilíbrio de antagonismos. Antagonismos 
de economia e de cultura. A cultura européia e a indígena [...] e a africana. A economia agrária e a pastoril. $O$ católico e o herege. [...] O grande proprietário e o pária. O bacharel e o analfabeto (Freyre, 2000: 125).

Esses antagonismos, no entanto, teriam sido dramaticamente amortecidos pela miscigenação e pelo personalismo, ambos referências centrais, para muito além do período colonial, não só à vida privada dos brasileiros como também às suas mais importantes instituições públicas.

Nem mesmo a inovadora interpretação marxista de Caio Prado Jr. distanciou-se daquela tese. Prado Jr. buscou compreender o porquê de, passados cinco séculos desde o início da colonização brasileira, não se ter constituído uma sociedade similar nem às europeias nem às das mais prósperas excolônias britânicas. O ponto de partida, afirma o autor, foi de imediato um tanto quanto distinto. Se nas zonas temperadas do continente americano prevaleceu a imigração de povoamento, ávida a construir um novo mundo, na área tropical e subtropical da América quase tudo contribuiu para um destino diverso: as condições naturais, muito distintas das europeias, faziam da nova terra um manancial quase inesgotável de produtos naturais comercializáveis. Dessa feita,

nos trópicos, [...] surgirá um tipo de sociedade inteiramente original. [...] No seu conjunto, e vista no plano mundial e internacional, a colonização dos trópicos toma o aspecto de uma vasta empresa comercial [...] destinada a explorar os recursos naturais de um território virgem em proveito do comércio europeu (Prado Jr., 1970:. 22).

Poder-se-ia pensar que esse traço inicial da ocupação brasileira teria se diluído com o tempo. Mas não foi isso o que, segundo Prado Jr., ocorreu: este sentido mercantil-explorador da colonização tropical "explicará os elementos fundamentais, tanto no social como no econômico, da formação e evolução histórica dos trópicos americanos" (Prado Jr., 1970: 22).

A bem da verdade, as principais obras de interpretação da sociedade brasileira produzidas na esteira da institucionalização e profissionalização das ciências sociais entre nós (Miceli et alii, 1989) não significaram qualquer subversão substantiva da "tese da excepcionalidade". Em Os donos do poder, Raymundo Faoro desenvolve a ideia de que a peculiaridade brasileira decorria do peso determinante da burocracia estamental na dinâmica so- 
cial, política e econômica brasileira. Argumenta que a importância desse estamento burocrático remontava a própria formação do Estado-nação português, em que a casa real desde pronto logrou ocupar lugar de destaque na sociedade e a suprimir qualquer poder paralelo que the representasse ameaça. Essa estrutura de poder, segundo Faoro, migrou para o Brasil nos tempos da colonização, razão pela qual desde o início as colônias inglesas e a principal colônia portuguesa na América mostraram-se tão distintas: enquanto os colonos ingleses no novo continente estabeleceram sua própria organização política e administrativa de maneira a resguardar suas tradições de autogoverno e respeito pela liberdade pública, na América portuguesa, os colonos viram-se sufocados pelo Estado absolutista e por sua burocracia centralizadora. Com isso, desde o início,

\begin{abstract}
o Estado sobrepôs-se, estranho, alheio, distante à sociedade, amputando todos os membros que resistem ao domínio. [Naquelas circunstâncias], nenhuma comunidade, nenhum contato, nenhuma onda vitalizadora flui entre o governo e as populações: a ordem se traduz na obediência passiva ou no silêncio (Faoro, 2001: 192).
\end{abstract}

Ainda nos anos 1950, é justamente a ideia de que a sociedade brasileira é algo peculiar em relação às mais poderosas e desenvolvidas sociedades europeias que conduz Guerreiro Ramos (1996) a advogar pela adoção de um método de "redução sociológica" capaz de adequar os conceitos e técnicas de pesquisa à nossa realidade. Daí, para o autor, o imperativo número um da "redução sociológica", a saber, a "assimilação crítica da produção sociológica estrangeira" a fim de evitar que obstáculos se interponham à compreensão adequada desta que era, para ele, uma realidade social particular em relação ao "centro".

Ao menos nesse sentido específico, não parece haver fortes divergências entre Ramos e Florestan Fernandes. Afinal de contas, conforme argumentou Florestan em uma de suas principais obras, em decorrência de sua condição dependente e periférica, a normatividade que entre nós se sedimentou após a transição em direção à ordem social capitalista revelou-se significativamente distinta daquela observada no centro do capitalismo. Segundo o autor, a modernização no Brasil

negligencia ou põe em segundo plano os requisitos igualitários, democráticos e cívico-humanitários da ordem social competitiva [...]. $\mathrm{Na}$ periferia, essa transição torna-se muito mais selvagem que nas 
5. Não por acaso, para o autor, não só não há entre nós partidos políticos representativos de classes sociais, como também não se encontra uma divisão harmoniosa entre os poderes republicanos e muito menos garantia de direitos individuais (Cardoso, 1972). nações hegemônicas e centrais, impedindo qualquer conciliação concreta, aparentemente a curto e longo prazo, entre democracia, capitalismo e autodeterminação (Fernandes, 1976: 256).

A bem da verdade, os principais pupilos de Florestan não destoaram deste diagnóstico. Fernando Henrique Cardoso, por exemplo, dizia que sociedades dependentes, como a brasileira, veem-se continuamente impossibilitadas de satisfazer as demandas de parte significativa de suas populações, mesmo após terem atingido consideráveis níveis de urbanização e atividade industrial. Nesses países, o "tipo associado de desenvolvimento" exigiu um aparato estatal autoritário e centralizador a fim de que fossem criadas condições políticas e sociais propícias aos imperativos das matrizes das corporações estrangeiras (Cardoso, 1980). A implicação disso foi que democracia representativa, grupos civis e demais formas de sociabilidade vivenciadas plenamente pelas sociedades capitalistas centrais não puderam se consolidar no Brasil. ${ }^{5}$ Octávio lanni, por sua vez, argumentava que, também em decorrência de sua condição dependente, o aparato estatal no Brasil foi levado a assumir atribuições e um tipo de postura em relação à economia e às organizações civis em função das quais instituições democráticas não conseguiram se firmar entre nós. Daí não terem prevalecido no Brasil, de acordo com o autor, as mesmas condições que permitiram aos países capitalistas centrais consolidarem valores e instituições burgueses para a maior parte de suas populações (Ianni, 1978).

Mesmo que partindo de pressupostos e pontos de vista consideravelmente distintos, análises e interpretações mais recentes também pouco divergiram dessa ideia-força. Roberto Da Matta, por exemplo, postulou que "continuamos a manter uma forte segmentação social tradicional, com todas as dificuldades para a criação das associações voluntárias que são a base da 'sociedade civil', fundamento do Estado burguês, liberal e igualitário, dominado por indivíduos" (Da Matta, 1979: 178-79). Por outro lado, é sugestiva a imagem do ornitorrinco aludida por Francisco de Oliveira para refletir a respeito do que é a sociedade brasileira contemporânea (Oliveira, 2003).

Ora, guardadas as irredutíveis especificidades e singularidades de cada um desses autores e perspectivas interpretativas, não é difícil encontrar certos aspectos que permeiam todos: uma sociedade em que as diferentes esferas e domínios sociais (Estado, mercado, sociedade civil, família) acham-se entremeados e, em certas circunstâncias, até mesmo justapostos; um aparato estatal extremamente centralizador, tão logo ele se constituiu como 
órgão político e administrativo; uma sociedade civil débil e incapaz de se organizar por si mesma; uma economia e um mercado frágeis, sempre distantes dos setores mais avançados do capitalismo internacional, e cujos atores mostram-se igualmente incapazes de gerar riqueza em proporção condizente com as demandas e necessidades da população; a prevalência de códigos privados de sociabilidade que tomam de assalto os espaços públicos em benefício de poucos; e sérios obstáculos ao florescimento de normas impessoais e universais, já que a transição em direção a uma constelação pós-tradicional jamais deixou de se mostrar claudicante. Nesse exato sentido, a imagem de "desvio" da experiência da modernidade entre nós ancora-se em nossas mais caras tradições de pensamento. A seguir, queremos mostrar como essa imagem é codificada no debate da sociologia política devotada à problemática da cidadania.

\section{Uma "cidadania à brasileira"?}

\section{Da nossa peculiaridade normativa}

Conforme sugerimos anteriormente, parte majoritária da sociologia brasileira contemporânea devotada ao estudo da experiência da cidadania no Brasil orienta-se pela tese segundo a qual a construção e vivência dos direitos e deveres entre nós revela-se algo distinto dos cenários observados no chamado "núcleo dinâmico da modernidade". Mas como essa ideia é codificada no campo da sociologia política?

Cabe, desde pronto, reconhecer a marcante influência das reflexões de Thomas Humphrey Marshall em torno da construção da cidadania na Inglaterra. Conforme é de amplo conhecimento, naquela obra seminal, T. H. Marshall define o "complexo da cidadania moderna" de forma a dividi-lo em três partes ou elementos, a saber, o civil, o político e o social. As instituições mais diretamente associadas aos direitos civis seriam, conforme o autor, as cortes de justiça, ao passo que o parlamento e os conselhos locais de governo seriam aquelas próprias aos direitos políticos. Por fim, o sistema educacional e os serviços sociais seriam as instituições primordialmente vinculadas aos direitos sociais. A sequência direitos/deveres civis $\rightarrow$ políticos $\rightarrow$ sociais, essencial na análise tripartite de Marshall, não deve ser vista como algo fortuito ou acidental. De acordo com o próprio autor, "a análise é, nesse caso, ditada pela história até mais claramente do que pela lógica" (Marshall, 1992: 8). T. H. Marshall pretende dizer com isso que a cidadania moderna, tal qual a conhecemos hoje, não foi integralmente institucionalizada de uma só vez, em um período curto de tempo. Na verdade, 
tratou-se de um longo processo que se estendeu por ao menos 800 anos, ao longo dos quais os séculos XVIII, XIX e XX constituíram-se como marcos importantes da experiência inglesa ao testemunharem a institucionalização das garantias civis, políticas e sociais, respectivamente.

Dois aspectos merecem destaque especial: em primeiro lugar, as reflexões de T. H. Marshall sintetizam de modo exemplar uma certa forma de se conceber a normatividade moderna que se revela hegemônica na sociologia política devotada à investigação da experiência da cidadania na modernidade; em segundo lugar, tal concepção converge de maneira notável com o que temos chamado de "tese da excepcionalidade normativa brasileira".

Qual seria, pois, essa maneira específica de se conceber a normatividade moderna? Trata-se, em primeiro lugar, de tomá-la como um dos subprodutos de processos de diferenciação e complexificação social (Tavolaro, 2008). Ao final desses processos, reza o argumento, as sociedades modernas teriam passado a se configurar em domínios distintos, cada qual especializado na execução de uma função (ou cada qual responsável pelo cumprimento de um determinado papel) e dinamizado por uma lógica própria. O "estilhaçamento" do tecido social e sua fragmentação em âmbitos distintos - Estado, mercado, família, sociedade civil etc. - teria impulsionado transformações normativas em direção ao aprofundamento de sua generalidade e de seu grau de abstração. Daí que tanto a legalidade quanto a moralidade modernas, diferentemente do que se observava na sociedade medieval, passam a ancorar-se em princípios universalistas, destacados de particularidades e costumes locais. Com isso, a normatividade moderna consegue, por um lado, servir de referência para relações sociais que atravessam e entrecortam domínios distintos da ordem social, regidos por imperativos e necessidades diversas. Por outro lado, ela mostra-se capaz de fazer frente às especificidades inerentes ao processo de diferenciação e complexificação sociais. Não por acaso, conforme defende T. H. Marshall, os direitos civis, políticos e sociais, tanto quanto as instituições que Ihes correspondem, dividiramse e tomaram rumos separados, com velocidades diversas e ancorados em princípios próprios (Marshall, 1992: 9).

O segundo aspecto fundamental é que, conforme essa maneira de conceber a vivência e construção de direitos e deveres, a normatividade moderna é também caudatária de processos intensos e profundos de secularização, que teriam conduzido à perda de legitimidade e posterior desintegração de concepções de mundo religiosas e tradicionais (Tavolaro, 2009). Isso 
significa que a legalidade e a moralidade modernas, além de gerais e abstratas, deixam de incorporar qualquer noção substantiva de vida (isto é, referências robustas do que é a "vida boa"); em segundo lugar, passam a justificar-se de maneira racional. Nesse sentido, a cidadania propriamente moderna proporciona garantias legais a indivíduos independentemente de suas convicções religiosas, razão pela qual nenhuma "modo particular de vida" tem prioridade sobre outros naquilo que concerne à vivência de direitos. A ancoragem dos direitos e deveres na figura do indivíduo, concebido de maneira universal e independente de suas origens socioeconômicas, tornou-se um dos pilares dessa concepção secularizada da cidadania.

O terceiro aspecto fundamental nessa maneira específica de se conceber a normatividade moderna é a noção segundo a qual ela também se ancora na separação entre domínios públicos e privados (cf. Poggi, 1978). É dessa separação que adviria o caráter impessoal da cidadania moderna: por um lado, conforme pode-se depreender pela definição proposta por Marshall, os direitos protegem e resguardam interesses individuais e garantem a individualidade e privacidade dos membros plenos da sociedade. Por outro lado, e ao mesmo tempo, definem as obrigações públicas dos indivíduos que, conforme aponta Marshall, devem agir "inspirados por um senso vívido de responsabilidade em vista do bem-estar da comunidade" (Marshall, 1992: 41). Isso não significa que a ordem normativa moderna institucionalize uma fissura insuperável entre domínios públicos e âmbitos privados. No entanto, ela demarca de maneira precisa uma e outra zonas de sociabilidade, além de estabelecer as referências normativas em torno das quais cada uma delas se estrutura e se dinamiza (Tavolaro, 2008).

Nessa linha de argumentação, observa-se uma espécie de efeito sinérgico entre, de um lado, diferenciação social, secularização societal e separação público-privado e, de outro, a construção e vivência plenas da cidadania moderna: quanto mais as sociedades em questão se mostrem diferenciadas, secularizadas e configuradas de maneira a delimitar claramente as fronteiras entre seus domínios públicos e privados, maiores são as condições de possibilidade para que os direitos e deveres, em sua acepção moderna, sejam plenamente vivenciados pelos cidadãos (Tavolaro, 2009). Além disso, a tomar pelo retrato proposto por Marshall para pensar o caso inglês, há uma nítida indicação de que os direitos sociais não poderiam ter se sedimentado da maneira efetiva como o foram a partir do final do século XIX caso não tivessem sido precedidos pela institucionalização e vivência de garantias de participação política. Ainda de acordo com aquela interpreta- 
ção, os direitos políticos também não poderiam ser minimamente praticados caso não tivessem sido precedidos pela institucionalização de garantias civis ("liberdade da pessoa, liberdade de fala, de pensamento e fé, o direito de propriedade e de concluir contratos válidos, e o direito à justiça"). Por isso é que, antes mesmo que lógica, a célebre sequência direitos civis $\rightarrow$ políticos $\rightarrow$ sociais possuía, segundo Marshall, uma justificativa de natureza histórica. Um último aspecto central naquele ensaio é a noção segundo a qual os direitos modernos resultaram de lutas e embates, levados a cabo por setores da população inglesa (essencialmente, "classes sociais") que reivindicavam o status de pertencimento pleno à sociedade em que viviam. Isso significa que o processo de construção da cidadania na Inglaterra deu-se em meio a conflitos, ao final dos quais os direitos puderam ser vivenciados como conquistas - e não como benesses conferidas "de cima para baixo". Essa situação ajudaria a entender o porquê de o processo de institucionalização da cidadania moderna ter se estendido por um período tão longo de tempo, via de regra permeado por violência e rupturas políticas.

Ora, justapondo-se essa maneira de caracterizar a normatividade moderna às interpretações do pensamento social brasileiro acima assinaladas, não parece restar outra saída a não ser codificar nossa experiência normativa sob o signo do "desvio". Eis algumas das evidências dessa aclamada peculiaridade societal, conforme a produção científica nacional: em primeiro lugar, fala-se de uma espécie de subversão da sequência histórica ao longo da qual os direitos e deveres teriam se institucionalizado (ou "juridificados") no Brasil. Isso significa que, para muitos, os direitos sociais antecederam as garantias políticas e mesmo as garantias civis (Santos, 1987). Outra evidência apontada para nosso suposto "desvio normativo" em relação ao núcleo da modernidade seria o fato de que aqueles mesmos direitos sociais, tão logo institucionalizados, jamais teriam deixado de ocupar lugar exageradamente privilegiado na tessitura normativa brasileira, em detrimento dos direitos políticos e civis (Carvalho, 2000). Sugere-se, ainda, que diferentemente das sociedades modernas centrais, o gozo pleno dos direitos e deveres deu-se por setores demasiadamente restritos da população, razão pela qual seu caráter universalista não teria qualquer efetividade prática no Brasil (Fernandes, 1976; Domingues, 1999). Cabe também destacar a frequência com que a literatura especializada argumenta que a "juridificação" dos direitos e deveres entre nós não resultou, na maior parte dos casos, de lutas e embates por meio dos quais setores desprivilegiados teriam conquistado garantias legais essenciais ao seu pertencimento social. Ao con- 
trário disso, assinala a literatura, a cidadania é tida e vivenciada como uma concessão, ou mais além, como uma "dádiva", que a qualquer momento pode ser retirada ao humor dos governantes (Sales, 1994). Não é difícil, também, deparar-se com o argumento de que concepções de mundo tradicionais e até mesmo mágicas se imiscuem na maneira pela qual os direitos e deveres são experimentados por amplas parcelas da população brasileira, razão pela qual se tornaria difícil vislumbrar a cidadania como uma construção legal dotada de positividade (Chauí, 1994). Não é de se estranhar, pois, que o ensaio de T. H. Marshall, tão logo publicado no Brasil (1967), tenha se tornado uma referência central aos próprios esforços explicativos e interpretativos empreendidos por nossa sociologia política devotada à investigação da experiência da cidadania entre nós: o caso inglês seria a nossa imagem invertida, a referência a partir da qual se poderia constatar de maneira nítida o "desvio normativo brasileiro". ${ }^{6}$

Mas cabe refletir um pouco mais a respeito dos pilares de sustentação da "tese da excepcionalidade normativa brasileira". Também aqui é possível perceber um jogo de espelhos por meio do qual a pretensa "experiência do núcleo da modernidade" é claramente contrastada com aquela tida como peculiar ao Brasil. Em primeiro lugar, a "tese da excepcionalidade" sustenta-se sobre a ideia de que o processo de diferenciação e complexificação social não se realizou entre nós na mesma profundidade e extensão observadas nas "sociedades modernas centrais". ${ }^{7}$ A implicação desse argumento é que Estado, mercado, sociedade civil, família e outras esferas de sociabilidade não se mostraram capazes de se constituir de maneira autorreferenciada; viram-se, dessa forma, impossibilitados de se dinamizar por meio de códigos e imperativos próprios. Evidência disso seria, por exemplo, a notável presença do Estado na dinâmica de âmbitos sociais os mais diversos, para além de suas fronteiras e prerrogativas estritas (lanni, 1971). Daí, também, a razão pela qual não haveria um arranjo equilibrado entre garantias sociais, políticas e civis, já que, na prática, essas dimensões da cidadania não se apresentariam de maneira tão nitidamente distintas entre si. Ou seja, em primeiro lugar, a "excepcionalidade normativa brasileira" seria uma decorrência de nosso baixo grau de diferenciação social.

Mas o problema não se esgota nesse ponto. A ideia do "desvio normativo brasileiro" se ancora também na noção segundo a qual o amplo e profundo processo de secularização observado no "núcleo da modernidade" não teria ocorrido entre nós nas mesmas proporções. Evidência desse fenômeno seria a forte presença da Igreja católica na dinâmica política brasileira, em
6. Apenas a título de exemplo, J. M. Carvalho argumenta o seguinte, após referência textual ao ensaio de Marshall: "Aqui não se aplica o modelo inglês. Ele nos serve apenas para comparar por contraste. [...] Quando falamos de um cidadão inglês, ou norte-americano, e de um cidadão brasileiro, não estamos falando exatamente da mesma coisa" (Carvalho, 2001: 1112).

\section{Cf., a esse} respeito, a maneira criativa com que Neves (1996) aborda os impasses do Estado de Direito no Brasil a partir de insights

proporcionados pela teoria a ação comunicativa de Habermas e da teoria de sistemas de Luhmann. Cf. ainda Domingues (1999; 2002). 
8. Lembremo-nos da obra clássica de Vitor Nunes Leal (1977) a respeito do fenômeno do "coronelismo". Mas vale também mencionar as reflexões de Maria Isaura Pereira de Queiroz a respeito do "mandonismo". diferentes momentos de nossa história. Outra evidência seria o significativo apelo de concepções de mundo religiosas no cotidiano do cidadão brasileiro, tanto nos âmbitos privados de convívio quanto na esfera pública (Bruneau, 1982). Tudo isso se tornaria um obstáculo à vivência dos direitos e deveres como garantias legais baseadas em princípios gerais, universais, abstratos e não substantivos. Por um lado, isso implicaria que, para amplos setores da população brasileira, a própria dinâmica política seria percebida como uma arena em que os desígnios de Deus se fariam sentir, ao mesmo tempo em que proteções legais seriam vivenciadas como dádivas concedidas de maneira benevolente também por intermédio divino. Por outro lado, esse incompleto processo de "destradicionalização" da ordem normativa significaria a impossibilidade de se estabelecer termos que regulamentassem o pertencimento à comunidade de cidadãos pautados pela noção da positividade da lei e de sua legitimidade racional (Souza, 2003). Portanto, em segundo lugar, nosso "desvio" seria decorrência do nível restrito de secularização societal.

Por fim, a "tese da excepcionalidade" se ancora na ideia segundo a qual a sociabilidade brasileira jamais teria deixado de ser circunscrita pela condição de porosidade entre os domínios privados e os âmbitos públicos. ${ }^{8} \mathrm{Argu}-$ menta-se que essa indistinção de esferas de sociabilidade via de regra dáse em benefício dos interesses particulares daqueles que ocupam posições privilegiadas no tecido social. Ao mesmo tempo, fala-se que dessa situação sempre decorreram efeitos perversos e nocivos à vivência das leis (e dos direitos e deveres, por certo) como normas impessoais e universais. Nessas circunstâncias, ao invés de protegerem as liberdades individuais, as leis capacitam alguns a gozar de "mais liberdade" do que outros (Telles, 1994). Assim sendo, a peculiaridade normativa brasileira decorreria também da indistinção entre os domínios sociais públicos e privados.

Diante disso, a construção e a vivência de direitos e deveres no Brasil moderno teriam ocorrido de maneira um tanto quanto peculiar em relação às sociedades centrais da modernidade a ponto de, no limite extremo, merecerem ferramentas cognitivas especiais. Ou seja, a despeito de compartiIhar com aquelas sociedades as mesmas referências legais e morais, essas últimas teriam adquirido uma configuração diversa e um efeito prático distinto em função da singularidade do padrão de sociabilidade sedimentado na ordem brasileira pós-tradicional. Os aspectos que confeririam singularidade à sociedade brasileira, e nos quais a "tese da excepcionalidade" se ampara, podem ser sociologicamente codificadas pelas noções 
de baixo grau de diferenciação social, secularização restrita e indistinção entre público-privado. Esse quadro teria contribuído sobremaneira para que, conforme sinalizamos anteriormente, os direitos e deveres em sua versão moderna tivessem se institucionalizado entre nós através de uma sequência histórica peculiar, tanto quanto por meio de um ritmo, extensão e profundidade diversos daqueles observados no "núcleo duro da modernidade" (Tavolaro, 2009). Exemplos históricos inúmeros foram utilizados para ilustrar e conferir legitimidade a essa tese. Falemos um pouco de um cenário específico que é resgatado de maneira recorrente na historiografia e ciências sociais brasileiras para exemplificar nossa alardeada singularidade.

\section{Embates normativos na "Era Vargas":}

Contraevidências à tese da excepcionalidade?

Conforme argumentamos anteriormente, a posição de destaque da "tese da excepcionalidade" no debate científico nacional deve-se também ao fato de ela amparar-se em evidências empíricas consistentes. Cabe salientar que a dinâmica social e política da chamada "Era Vargas" (1930-1945) é comumente vislumbrada como uma confirmação exemplar de nosso "desvio normativo" (Santos, 1987; Carvalho, 2001; Saes, 2001, para citar apenas alguns). A princípio, naquele período que parte importante da historiografia brasileira aponta como um marco do Brasil moderno (Fausto, 1985), encontraríamos sem grandes problemas todos os ingredientes da suposta "singularidade da modernidade no Brasil". Aquele cenário é, com muita frequência, assim caracterizado: um aparato estatal inflado, cujas ações e presença extravasam seus próprios âmbitos em direção ao mercado e à sociedade civil; uma sociedade civil frágil e desorganizada, permeada por visões de mundo tradicionais e incapaz de lutar por seus anseios e projetos sociais; uma esfera pública débil, manchada e subjugada pelos interesses privados de setores restritos da população; uma economia recalcitrante e vulnerável aos eventos e humores internacionais, sempre ansiosa por apoio estatal; some-se a isso, é claro, a existência de uma configuração de direitos em que prevalece a dimensão social em detrimento das dimensões política e civil. Não por acaso, esse retrato converge com os principais pontos de apoio dos diagnósticos traçados por figuras-chave do pensamento social brasileiro a respeito de nossa suposta "singularidade societal" (conforme pode-se depreender pela brevíssima menção a Nabuco, Silvio Romero, Alberto Torres, Oliveira Vianna, e demais anteriormente aludidos). 
Ora, seria possível, nesse exercício de análise crítica a uma tese bastante consolidada, realizar uma interpretação alternativa de sua principal evidência empírica? Ou seja, em que medida a experiência da cidadania na "Era Vargas" poderia ser tomada como um contraexemplo da "tese da excepcionalidade" ao invés de seu reforço privilegiado? E mais: até que ponto aquela configuração tão amplamente vislumbrada como peculiar a uma "sociedade periférica" guarda semelhanças com experiências de certas "sociedades centrais"?

O primeiro aspecto a ser assinalado é que a configuração de direitos e deveres característica do período 1930-1945 foi apenas uma dentre outras observadas ao longo de nossa história recente. A menos que se atribua às ordens constitucionais brasileiras um mero papel ideológico - como se elas não tivessem outro efeito prático senão mascarar relações de poder que, em sua essência, teriam permanecido inalteradas - é difícil desconsiderar o fato de que, desde 1824, tivemos nada menos que oito constituições. A despeito de certos aspectos permanecerem inalterados nos vários textos constitucionais, cada um deles guarda especificidades e ênfases distintas. Como desconsiderar, por exemplo, que a Constituição de 1824 garantia direito de voto a uma ampla parcela da população, muito maior do que em qualquer país europeu daquele mesmo período (CarvaIho, 2001)? O que dizer do novo padrão de relação Estado-religião inaugurado pela Constituição de 1891, na contramão do artigo 5ㅇ da Carta de 1824, que havia estabelecido o catolicismo apostólico romano como a religião oficial do Império (Groot, 1995)? E quanto à inédita combinação de preceitos liberais e corporativistas encontrados na Carta de 1934, a contragosto tanto do establishment varguista como dos setores empresariais (Gomes, 1986)? Como, por outro lado, desconsiderar a acentuação do corporativismo na ordem constitucional do Estado Novo, em detrimento das referências normativas liberais que haviam prevalecido no período 1891-1930 (Camargo et alii, 1989, Vianna, 1989)? Haveria razão, ao mesmo tempo, para conferir pouca relevância à retomada dos princípios liberais pela Carta de 1946, que instituiu uma ordem política pluripartidária, que perduraria quase duas décadas (Souza, 1983)? Como interpretar a virada autoritária observada nas ordens legais de 1967 e 1969, nas quais "medidas de emergência" (cf. o capítulo $V$ da Constituição de 1967 e os Atos Institucionais do período 1964-1969) colocaram as garantias civis e políticas em situação de extrema fragilidade? Por fim, o que dizer do equilíbrio observado na "Constituição cidadã" de 1988 no tocante aos direitos políticos, sociais e civis (Fausto, 2001)? Uma vez mais: a não ser 
que desconsideremos os efeitos práticos específicos de cada uma das configurações de direitos e deveres embutidas nas várias constituições, não haveria por que atribuir a qualquer uma delas (por exemplo, a constelação que se sedimentou ao longo e ao cabo da "Era Vargas") o status de "exemplar par excellence da experiência da cidadania no Brasil". Ao invés disso, caso entendamos cada uma das ordens constitucionais como sendo a resultante de disputas envolvendo projetos normativos distintos que coloriram os diversos cenários sociopolíticos brasileiros, torna-se possível vislumbrar com maior precisão a complexidade e variedade dos processos de construção e vivência dos direitos e deveres no Brasil pós-tradicional.

O segundo aspecto a ser considerado diz respeito justamente à dimensão agonística, por assim dizer, do processo de construção da cidadania na "Era Vargas". Conforme salientamos anteriormente, também é comum a imagem de fragilidade atribuída à sociedade civil brasileira, em função da qual os direitos e deveres instituídos ao longo dos anos 1930-1945 teriam sido vivenciados como "dádivas" e não como conquistas. A "passividade", pois, teria sido a regra na experiência da cidadania no Brasil. Ocorre, porém, que ao menos desde o seminal trabalho de Evaristo de Moraes Filho (1978) sabemos que essa imagem "demiúrgica" do Estado varguista - alimentada pelo próprio establishment como uma estratégia de opressão e supressão de projetos alternativos de sociedade - não encontra ressonância na turbulência política daquele período. Desde a década de 1970, parcela importante da historiografia e ciências sociais brasileiras tem resgatado a riqueza da dinâmica sindical e política (amplamente considerada) não só da "Era Vargas" como das duas décadas que a precederam (Carone, 1974; Decca, 1981; Gomes, 1979, 1994; Munakata, 1981; Paranhos, 1998; Rodrigues, 1986; dentre outros). Esse resgate revelou a existência de uma gama considerável de projetos normativos que habitavam aquele cenário político e social, vocalizados por setores os mais variados da sociedade: trabalhadores urbanos (organizados ou não) com perfis ideológicos os mais díspares (Araújo, 1998), as classes médias emergentes (Saes, 1985), os diferentes projetos dos setores mais intelectualizados da sociedade (Lahuerta, 1997; Medeiros, 1978), as distintas demandas observadas nas classes empresariais urbanas e rurais (Diniz, 1978; Leme, 1978), as disputas no interior da igreja católica (Krische, 1979; Lustosa, 1983), os embates entre os militares (Borges, 1992; Castro, 1995), sem esquecermos, obviamente, dos próprios conflitos explosivos envolvendo os atores políticos que ocupavam os órgãos administrativos e de representação (Gomes, 1980; D’Araújo, 1999). Ora, 
muitos dos preceitos e garantias sociais institucionalizados na "Era Vargas" haviam sido bandeira de luta de movimentos sindicais e setores médios antes mesmo do Golpe de 1930 (Gomes, 1987; Forjaz, 1989; Simão, 1981) e continuaram a sê-lo na década e meia subsequente. Essa foi uma das razões da dificuldade enfrentada pelo establishment varguista para fazer prevalecer o seu projeto normativo (Vianna, 1989), em detrimento de outros que coabitavam a arena política. Esses dados servem para ao menos levantar dúvidas à imagem de "passividade" (ou, como muitos autores cultivaram, de "bestialidade popular") comumente atrelada à vivência da cidadania no Brasil e, em particular, ao cenário observado na "Era Vargas". Conforme atesta a bibliografia sobre o período, havia um leque considerável de projetos de normatividade, alguns deles compatíveis com o teor da legislação que emanava do Ministério do Trabalho, Indústria e Comércio e demais órgãos estatais, enquanto outros mostravam-se absolutamente divergentes.

Cabe ainda ressaltar que cada uma das ordens constitucionais que coloriram o cenário legal brasileiro embutia concepções distintas a respeito do tipo de relação Estado - mercado - sociedade civil, Estado - religião, e esferas públicas - âmbitos privados. Como, então, sustentar o pressuposto da existência de um único padrão de sociabilidade, pretensamente peculiar à sociedade brasileira pós-tradicional (isto é, de um certo tipo de diferenciação social, de um padrão específico de secularização e de um perfil peculiar de separação público - privado)? Seria correto afirmar que a religião cumpre hoje o mesmo papel que ela exerceu nas vidas pública e privada da sociedade brasileira nos anos 1930? Contra a imagem de uma progressiva secularização, o que dizer do vigor conquistado pelas seitas protestantes a partir dos anos 1980? Por outro lado, como interpretar o papel da Igreja católica na resistência à ditadura militar e a defesa de alguns de seus setores pela liberdade civil e política (Lustosa, 1991)? Variações similares podem ser notadas também em relação aos diferentes tipos de relação Estado - mercado - sociedade civil observados ao longo da história da sociedade brasileira pós-tradicional: a despeito da constante presença do Estado como estimulador da dinâmica econômica (de resto, algo absolutamente comum em toda e qualquer sociedade moderna), caberia desconsiderar a existência de padrões de diferenciação social tão distintos como aqueles experimentados nos períodos 1891-1930, 19301945 e pós-1988 (Ianni, 1971; Francisco de Oliveira, 2003)? Teve, o Estado brasileiro, na década de 1990, o mesmo tipo de presença na dinâmica social, política e econômica observada nos períodos 1930-1945 e 1964- 
1985? O que dizer do padrão capitalista-liberal que prevaleceu entre 1891 e 1930? Por fim, a tomar pelos vários tipos e graus de atuação da sociedade civil nos diferentes períodos da história brasileira recente, faz sentido afirmar a existência de um invariável padrão de relação entre os domínios públicos e privados? Não teriam ocorrido mudanças significativas na esfera doméstica e, por conseguinte, na configuração da vida familial nas últimas décadas? O que dizer da estrutura e dinâmica da esfera pública brasileira? Teria ela permanecido a mesma nos anos 1964-1985 em comparação com o período que a precedeu? O que dizer das transformações por que passaram os domínios públicas desde o início dos anos 1980 (Avritzer, 2002; Costa, 1994)?

Na verdade, esses questionamentos ensejam dúvidas em relação à própria imagem segundo a qual o padrão de sociabilidade cristalizado na "Era Vargas" seria peculiar à "periferia" e, nesse sentido, divergente das experiências das "sociedades modernas centrais". Apenas a título de ilustração, cabe reconhecer que as décadas que se seguiram a Primeira Guerra Mundial foram marcadas, em escala global, por forte resistência a preceitos políticos, econômicos e normativos de cunho liberal. Essa resistência mostrouse mais ou menos acentuada em diferentes sociedades (inclusive nas "centrais"), com implicações políticas e sociais bastante distintas: O "New Deal" nos Estados Unidos pós-1929, o regime totalitário na Alemanha após a débâcle da República de Weimar, a experiência totalitária na Itália de Mussolini, o domínio da política trabalhista e social-democrata na Inglaterra e outros países europeus no período posterior a Segunda Guerra são apenas alguns exemplos. Cabe lembrar que, naquelas décadas, não era algo incomum a forte presença do Estado na dinâmica social, acompanhada da ênfase legal nas prerrogativas sociais (em alguns casos, em detrimento dos direitos civis e políticos). A própria imagem da secularização, que durante tanto tempo animou a produção sociológica, hoje vê-se abalada por estudos que têm resgatado o papel público e privado fundamental que a religião jamais deixou de ter em várias das chamadas "sociedades modernas centrais" (Casanova, 1994).

Parece-nos, pois, problemático assumir a existência de uma excepcionalidade normativa brasileira, que teria na configuração de direitos e deveres construída e vivenciada na "Era Vargas" seu exemplo primordial. A consideração de algumas das críticas da sociologia política contemporânea ao ensaio de T. H. Marshall pode nos ajudar a relativizar o pretenso hiato "centro" - "periferia" sobre o qual se sustenta essa a tese. 


\section{Algumas reflexões sociológicas contemporâneas: O binômio centro-periferia em questão}

Ao longo das seis décadas desde seu pronunciamento e posterior publicação, as reflexões de Marshall a respeito do processo de construção e vivência da cidadania na Inglaterra mostraram-se referência fundamental em trabalhos de teoria social (como em Parsons, 1971; Honneth, 1995; Santos, 1997), de teoria política e democrática (Cohen \& Arato, 1994; Habermas, 1998), tanto quanto de esforços interpretativos de natureza histórico-sociológica (Bendix, 1996). Ao mesmo tempo, porém, é mister reconhecer que, nas últimas duas décadas, aquele ensaio passou a ser alvo crescente de inúmeras críticas em torno de aspectos os mais variados (Tavolaro, 2008). Giddens (1996), por exemplo, chama atenção para o fato de Marshall não ter explorado devidamente os limites implícitos na democracia liberal. Ao lado disso, menciona uma série de transformações sociais contemporâneas que teriam conduzido aquela interpretação à condição de obsolescência. Dentre elas, destacam-se o aprofundamento do processo de "destradicionalização", do qual o movimento feminista seria sujeito exemplar, os crescentes níveis de reflexividade social, que teriam posto abaixo a estabilidade social pressuposta no modelo de Marshall (condição sine qua non às políticas sociais e instituições do welfare state) e a globalização, que teria imposto limites aos contornos nacionais da cidadania marshalliana. Claus Offe (1996), por sua vez, chama a atenção para transformações no mundo do trabalho responsáveis por problematizar um dos pressupostos-chave da concepção de Marshall, a saber, a existência de coletividades e organizações de classe amplas, autoconscientes e bem organizadas, capazes de lutar de maneira significativamente uníssona em direção à ampliação de certos direitos de cunho universal.

Já Will Kymlicka (1995) argumenta que a teoria da integração social embutida na interpretação de T. H. Marshall revela-se insensível às demandas e conflitos de cunho étnico-cultural observadas de maneira crescente nas sociedades multiétnicas contemporâneas. Nesse caso, afirma Kymlicka, a ênfase no corte classista mostra-se insuficiente e demasiadamente limitada. A bem da verdade, esses novos tipos de clivagens, às quais aquele ensaio não conseguiria fazer frente, são salientados por inúmeras outras avaliações críticas. Nancy Fraser e Linda Gordon, por exemplo, sustentam que

quando questões de gênero e raça são colocadas no centro da investigação, elementos-chave da análise de Marshall tornam-se problemáticos. Sua periodização dos três estágios da cidadania, por exem- 
plo, cabe somente na experiência dos homens trabalhadores brancos, uma minoria da população. Suas distinções conceituais entre cidadania civil, política e social pressupõem, ao invés de problematizar, a hierarquia racial e de gênero (Fraser \& Gordon, 1994: 93).

Na mesma direção, Katrina Gorjanicyn (2000) afirma que a teoria de Marshall "era baseada sobre a premissa de que as sociedades modernas são etnicamente e culturalmente homogêneas", fato desmentido por uma análise atenta do cenário social contemporâneo de países como a França.

Não por acaso, muitas análises têm salientado o alcance limitado do esquema conceitual que ampara a interpretação marshalliana. Nessa linha, Robert van Krieken defende que a despeito da possibilidade de se aplicar a abordagem de Marshall a países como França e Estados Unidos,

o que foi deixado de fora do retrato foram as implicações para uma teoria sociológica da cidadania e da democracia de seus fracassos mais espetaculares, a saber, a emergência do fascismo na Alemanha, Itália e Espanha, e especialmente o mais dramático exemplo da remoção - ou melhor, extermínio - dos direitos de cidadania no Holocausto" (van Krieken, 2000: 126).

Já Tom Bottomore joga luz sobre cenários do Leste europeu nas décadas que se seguiram a Segunda Guerra Mundial. Segundo o autor,

a cidadania nessas sociedades socialistas [...] tinha [...] um caráter bem diferente daquela considerada por Marshall na Grã-Bretanha e, por implicação, de outras sociedades da Europa ocidental. Ao invés de uma progressão desde os direitos civis aos políticos, e então a um crescimento dos direitos sociais, tal como Marshall havia concebido, essas sociedades estatal-socialistas totalitárias estabeleceram alguns importantes direitos sociais ao mesmo tempo em que virtualmente extinguiram importantes direitos civis e políticos; deveria ser observado que um fator que facilitou esse processo foi que muitos dos países envolvidos não possuíam qualquer tradição segura de direitos civis e políticos, e pouca experiência democrática antes de sua transformação “socialista" (Bottomore, 1992: 63).

De maneira mais sistemática, e refletindo a respeito da condição dos imigrantes em diversos países ao redor do globo, Yasemin Soysal (1995) desta- 
ca a existência de ao menos quatro grandes modelos de pertença (membership) e de padrões de incorporação: um modelo "corporativista" (caso da Suécia e Holanda), um modelo "liberal" (Suíça e Grã-Bretanha), um modelo "estatista" (França) e um modelo "fragmental" (países árabes em torno do Golfo) - a Alemanha, segundo a autora, ficaria entre o padrão "corporativista" e o "estatista". Por fim, a esse respeito, Michael Mann observa que a consideração de Marshall

é inteiramente a respeito da Grã-Bretanha. Não há uma única menção a qualquer outro país. Eu escrevo Grã-Bretanha ao invés de Reino Unido porque não há referência à Irlanda do Norte, que não caberia bem em sua teoria (Mann, 1996: 126).

Diante disso, Mann defende a existência de ao menos cinco distintas estratégias de institucionalização da cidadania moderna (todas elas eficientes, cada qual a seu modo) decorrentes de cenários pré-industriais distintos. São elas: liberal (Estados Unidos), reformista (Grã-Bretanha), corporativista (países escandinavos), fascista (Alemanha Nazista) e autoritário-socialista (União Soviética).

Abundam também as críticas em relação ao perfil teleológico e a um certo "evolucionismo" embutidos na interpretação marshalliana, que teriam levado muitos analistas a acreditarem na inexorabilidade da universalização dos direitos na esteira da modernização. Bryan Turner, por exemplo, argumenta que os contornos nacionais da cidadania moderna (e seu correspondente sistema político, sua língua e seu sistema de bem-estar) podem ter significado uma considerável restrição ao caráter universalista da Igreja cristã medieval que lhe precedera. Ademais, esse traço evolucionista é passível de ser questionado sob o argumento de que

não está claro que os direitos civis e políticos precederam os direitos sociais. Por exemplo, poderia ser argumentado que enquanto as muIheres alcançaram um certo nível de direitos sociais, muitos de seus direitos civis e políticos permaneceram relativamente subdesenvolvidos em inúmeras sociedades modernas. Dessa forma, diferentes grupos sociais podem experimentar a taxa de mudança social em diferentes maneiras e dentro de uma diferente ordem seqüencial (Turner, 1993: 8).

Isso leva Turner (1993: 9) a salientar que há dúvidas "se existe uma única versão de cidadania, ou se poderiam existir muitas diversas e diferentes 
formulações do princípio da cidadania em diferentes tradições sociais e culturais".

A sequência histórica direitos civis/políticos/sociais foi ainda o alvo principal da investigação crítica de Margaret Somers (1993). Através de uma rica e pormenorizada análise de cunho histórico-sociológico, cujo foco foi diversas regiões da Inglaterra dos séculos XVII e XVIII, Somers procurou revelar aspectos que permaneceram obscurecidos na reconstrução histórica de Marshall. Para ela, os limites da análise marshalliana decorrem da maneira como as dimensões tempo, espaço e agência permeiam aquela interpretação. Quanto à dimensão temporal, Somers observa que, nos séculos XVII e XVIII, reivindicações e práticas em torno de direitos políticos e sociais mostraram-se combinadas àquelas voltadas às garantias civis. Daí o equívoco de concebê-las de maneira sequencial. Em relação à dimensão espacial, Somers argumenta que Marshall errou ao supor que a supressão de práticas locais por práticas nacionais foi uma condição à emergência e florescimento da cidadania moderna, algo que supostamente teria conduzido à sua uniformidade em todo território inglês. Ao contrário disso, a autora notou a existência de padrões variados de implementação legal nas distintas regiões da Inglaterra. Tais variações dependeram justamente de diferenças em relação à geografia política e ao tipo de interação entre leis nacionais e culturas políticas regionais. Por fim, quanto ao problema da agência, Somers defende que a análise de Marshall se equivocou ao supor que cada estágio do desenvolvimento da cidadania na Inglaterra traduziu as necessidades de classes sociais emergentes e distintas. Se esse fosse o caso, os agentes por excelência daquelas transformações normativas que marcaram a emergência da cidadania moderna teriam sido prioritariamente os proprietários rurais no século XVIII (direitos civis), as classes médias industriais no século XIX (direitos políticos) e as classes trabalhadoras no século XX (direitos sociais). No entanto, Somers observa que não só inexistia a uniformidade intraclasse presumida no esquema marshalliano como, em muitos casos, alianças entre agentes de classes sociais distintas revelaram-se determinantes à institucionalização da cidadania em diferentes regiões da Inglaterra. Para tal, argumenta Somers, a existência ou não de uma esfera pública vibrante mostrou ser uma variável independente das mais relevantes.

Qual seria, para os propósitos do presente artigo, a importância dessas observações críticas ao ensaio de T. H. Marshall? Ora, parece-nos serem elas sintomáticas de um desconforto - para não dizer mal-estar - crescen- 
te no seio da teoria sociológica contemporânea em relação à maneira como a sociabilidade moderna tanto quanto seus principais atores e projetos são classicamente concebidos. Ou seja, essas críticas à interpretação marshalliana sugerem que pressupostos-chave do discurso sociológico da modernidade, tomados como padrões de medida a partir dos quais experiências societais "periféricas" são avaliadas, não encontram ressonância nem mesmo nas chamadas "sociedades modernas centrais". Assim, por um lado, os críticos de Marshall revelam que variações consistentes na configuração da cidadania moderna podem ser observadas não só entre diferentes regiões do globo como também no interior do próprio "berço da modernidade" (a Europa Ocidental). Conforme parece sugerir essa bibliografia, tais variações ocorrem justamente em virtude de diferenças quanto às maneiras como Estado - mercado - sociedade e outras esferas de sociabilidade se relacionam (Bottomore, 1992; Mann, 1996), tanto quanto das maneiras como os âmbitos públicos e privados são definidos e dinamizados (Turner, 1990; Somers, 1993) e, por fim, dos diversos papéis públicos e privados assumidos pela religião em diferentes setores da população (Casanova, 1994; Tibi, 2006). Paralelamente, as críticas indicam a existência de inúmeros outros agentes sociais além daqueles contemplados por Marshall, cujos anseios, interesses e projetos de sociedade mostram-se tão importantes à definição da ordem normativa das sociedades contemporâneas quanto aqueles atribuídos às classes sociais tradicionalmente concebidas (Kymlicka, 1995; Offe, 1996; Fraser \& Gordon, 1994).

A bem da verdade, essas considerações convergem de maneira notável com avaliações contemporâneas direcionadas ao "discurso sociológico hegemônico da modernidade". É esse o caso de ao menos dois debates atuais pertinentes ao presente exercício crítico da "tese da excepcionalidade", a saber, aquele em torno da ideia de "modernidades múltiplas" e o debate sobre a chamada "condição pós-colonial".

Shmuel Eisenstadt, talvez a figura de maior destaque nas reflexões em torno da ideia de "modernidades múltiplas", lança um desafio tanto às "teorias clássicas da modernização" quanto às "análises sociológicas clássicas de Marx, Durkheim e Weber". Segundo o autor, em ambos os casos, tomou-se por certo que o programa cultural europeu da modernidade e suas instituições correspondentes ganhariam os quatro cantos do mundo. Ocorre porém que, ainda segundo o autor, a partir de meados do século $X X$, "os efetivos desenvolvimentos nas sociedades em modernização re- 
futaram os pressupostos homogeneizantes e hegemônicos desse programa ocidental da modernidade" (Eisenstadt, 2000: 1). Isso porque, se é verdade que

uma tendência geral em direção à diferenciação estrutural desenvolveu-se através de um amplo leque de instituições na maioria dessas sociedades - na vida familial, nas estruturas econômicas e políticas, urbanização, educação moderna, comunicação de massa, e orientações individualistas - as maneiras pelas quais essas arenas foram definidas e organizadas variaram consideravelmente, nos diferentes períodos de seu desenvolvimento, dando origem a padrões institucionais e ideológicos múltiplos (Eisenstadt, 2000: 1).

O autor adverte que, no caso das sociedades em modernização, tal multiplicidade não significou a mera continuidade de suas tradições uma vez que os padrões institucionais e ideológicos alcançados são, sim, distintamente modernos, "baseados no projeto ocidental originário, a despeito de terem sido fortemente influenciados por premissas culturais, tradições e experiências históricas específicas" (Eisenstadt, 2000: 1-2). Isso significa que, para Eisenstadt, modernidade e ocidentalização não devem ser tomados como termos idênticos, pois "os padrões ocidentais da modernidade não são as únicas modernidades 'autênticas', a despeito de gozarem de precedência histórica e de continuarem a ser um ponto de referência básico para os outros" (Eisenstadt, 2000: 2-3). São essas mesmas preocupações que levam José Casanova a defender que
é tempo de abandonar a visão eurocêntrica de que os desenvolvi- mentos do ocidente europeu moderno, incluindo a secularização da cristandade ocidental, são processos gerais universais. Quanto mais se adota uma perspectiva global, mais torna-se óbvio que a seculari- zação drástica das sociedades européias ocidentais é na verdade um fenômeno excepcional, com poucos paralelos em outros lugares além das sociedades de povoamento europeu, tais quais a Nova Zelândia, Quebec ou Uruguai (Casanova, 2006: 84-85).

Ora, parece-nos extremamente importante o fato de esse debate esforçarse inclusive para desmontar a imagem de unidade e homogeneidade atrelada ao próprio "berço da modernidade". Nesse sentido, Björn Wittrock argumenta que 
mesmo se a atenção for limitada aos processos de industrialização e democratização na América do Norte e Europa ocidental no decorrer dos séculos XIX e XX, é evidente que sempre houve diferenças muito substanciais entre os países. Não é verdade que todos esses países tiveram de maneira geral tipos similares de instituições econômicas e políticas nesse período histórico (Wittrock, 2000: 33).

Ao invés disso, afirma o autor, diferenças podem ser notadas nas maneiras como a sociedade, a economia de mercado e as formas políticas se organizaram.

Como é de se esperar, essas colocações gerais em torno da noção de "modernidades múltiplas" reservam um lugar especial à América Latina. Assim, Eisenstadt sugere que as Américas, muito antes do que a Ásia (Japão, China ou Índia) ou as sociedades islâmicas, foram o primeiro lugar em que se desenvolveram padrões distintos de modernidade. Isso ocorreu, segundo o autor, através de um discurso de confronto com a Europa (especialmente Inglaterra e França). Mas mesmo no interior do "Novo Continente", importantes diferenças tiveram lugar, notadamente entre os Estados Unidos e a América Latina. "Na América Latina, pontos de referência "externos" - mesmo que frequentemente ambivalentes - permaneceram cruciais" (Eisenstadt, 2000: 13-14). Como bem observa Volker Schmidt (2007), essa postulação abre a possibilidade de se conceber a existência de uma "modernidade latino-americana" em simultaneidade a uma "modernidade anglo-saxônica", tanto quanto a uma "modernidade islâmica", "chinesa" e assim por diante - ou seja, abre a incômoda possibilidade de se pensar a experiência da modernidade nos contornos civilizacionais traçados por Samuel Huntington (1996). Diante disso, poder-se-ia dizer que, a despeito de ter seu estatuto clássico de "padrão de medida" relativizado, a experiência da Europa ocidental (ou "anglosaxônica") permaneceria a referência primordial a partir da qual especificidades e peculiaridades societais observadas em cenários modernos outros seriam identificadas enquanto tais. Portanto, ainda que fosse sua intenção, o debate em torno da noção de "modernidades múltiplas" não teria logrado dissipar por completo a imagem de "desvio" que permeia a teoria sociológica clássica e as teorias da modernização.

Ocorre que, conforme sugere Dilip Gaonkar, a "globalização da modernidade" não ocorreu desacompanhada da consciência e percepção das próprias populações que passaram por tais transformações: 
a modernidade viajou do Oeste para o resto do mundo não apenas em termos de formas culturais, práticas sociais e arranjos institucionais, mas também como uma forma de discurso que interroga o presente (Gaonkar, 2001: 14-15).

Isso significa que, de acordo com essa produção, discursos outros - que não aqueles do chamado "centro" - a respeito do que é a experiência da modernidade passaram a ser produzidos e disseminados a partir das próprias "margens" dessa experiência, à luz da percepção de que a modernidade "não possui mais um centro orientador ou narrativas-mestras para acompanhála" (Gaonkar, 2001: 14). Coletâneas como A colonialidade do saber: Eurocentrismo e ciências sociais, organizadas pela Clacso (Lander, 2005) apontam justamente para essa direção. No interior desse campo de estudos, argumenta-se, por exemplo, que

o fato de que os europeus ocidentais imaginaram ser a culminação de uma trajetória civilizatória desde um estado de natureza, levouos também a pensar-se como os modernos da humanidade e de sua história, isto é, como o novo e ao mesmo tempo o mais avançado da espécie. [...] os europeus imaginaram também serem não apenas os portadores exclusivos de tal modernidade, mas igualmente seus criadores e protagonistas (Quijano, 2005: 239).

Da crítica a essa autoimagem de protagonista par excellence da modernidade, avança-se em direção ao resgate da "'outra face' oculta e essencial à Modernidade: o mundo periférico colonial, o índio sacrificado, o negro escravizado, a mulher oprimida, a criança e a cultura popular alienadas, etc" (Dussel, 2005). Nesse caso, o que se quer enfatizar é justamente o ponto de vista dos sujeitos que se situam nos "entrelugares" (Bhabha, 1998), isto é, aqueles que, da perspectiva do "centro", habitam as "margens" e cujas vozes, em função disso, são com frequência tidas como não representativas da experiência daquele mesmo "centro", muito embora revelam-se condição sine qua non para sua existência (Appiah, 1992). Quer-se, também, jogar luz sobre os efeitos de poder que decorrem de conceitos e noções que a princípio apresentam-se como neutros, mas que na realidade reforçam assimetrias e mascaram heterogeneidades que perpassam e entrecortam toda a experiência social contemporânea, seja a do "núcleo", seja a da "margem" (Gilroy, 1993; Said, 1994; Pratt, 1999). Resta-nos refletir a respeito das implicações dessas ponderações à problemática da construção e vivência da cidadania no Brasil. 


\section{Considerações finais}

À guisa de conclusão, gostaríamos de retomar as questões com as quais iniciamos o presente artigo. Primeiramente, haveria algum ônus em manter-se atrelado à "tese da excepcionalidade"? Entendemos que essa tese tende a projetar uma imagem hipostasiada da experiência dos direitos e deveres da sociedade brasileira pós-tradicional. Isso ocorre na medida em que: 1 . Ao se identificar uma certa configuração de cidadania como sendo peculiar ao caso brasileiro, variações que ocorreram ao longo de nossa recente história são obscurecidas; 2 . Tal tese também deixa de atribuir a devida relevância à dimensão agonística da construção de direitos e deveres entre nós; daí que projetos alternativos de normatividade, distintos daqueles que prevaleceram na ordem constitucional, não são tidos como representativos da vivência da cidadania no Brasil; 3. Por fim, a "tese da excepcionalidade" assume a existência de um grau elevado de unidade e estabilidade na experiência do "centro", por sua vez adotada como padrão para se avaliar o cenário brasileiro, que não necessariamente corresponde às sociedades do chamado "núcleo dinâmico da modernidade"; assim, "centro" e "periferia" são vislumbrados como essencialmente separados por um hiato, ele mesmo tido como sintoma de imaturidade política e desvio da experiência da modernidade no Brasil.

A segunda questão que nos orientou neste esforço crítico foi: haveria uma maneira alternativa e mais adequada de se interpretar a construção e vivência da cidadania no Brasil? Parece-nos que tanto a produção em torno da ideia de "modernidades múltiplas" quanto o debate a respeito da "condição pós-colonial" sugerem a inadequação do binômio "centro-periferia" diante das inúmeras transformações sociais contemporâneas. É sobre esse binômio que, em boa medida, se sustentam imagens de "desvio" e de "excepcionalidade" atreladas a experiências societais outras que não as do chamado "núcleo dinâmico da modernidade". Na verdade, entendemos que o campo discursivo em torno da "condição pós-colonial" avança passos mais firmes nessa direção ao buscar: 1 . Demonstrar as descontinuidades que permearam o processo de construção histórica e epistemológica da "modernidade europeia", revelando o peso determinante que outras experiências societais tiveram e permanecem tendo, a despeito de sua hegemonia e de sua pretensão de protagonista par excellence da modernidade; 2. Revelar a existência de movimentos, atores sociais, estilos de vida e projetos de sociedade no próprio "centro" que, a despeito de lhe serem constitutivos, são comumente obscurecidos pelo "discurso hegemônico da 
modernidade", na exata medida em que divergem da episteme a partir da qual tal "centro" constrói autoimagens e as transforma em padrão de medida para as demais experiências societais contemporâneas; 3. Demonstrar o papel ativo de cenários tradicionalmente tidos como "marginais" ou "periféricos" na própria experiência da modernidade.

Ora, suspender o binômio "centro-periferia" implica justamente problematizar a imagem de que a experiência da modernidade no Brasil, tanto quanto da ordem normativa que se constituiu em sua esteira, é algo essencialmente peculiar em relação ao chamado "berço da modernidade". Parece-nos legítimo, pois, perguntar se haveria algum referencial apto a orientar a investigação sociológica a respeito do padrão de sociabilidade moderno que se revela capaz de diferenciá-lo de outras formas de sociabilidade sem, contudo, ossificá-lo e essencializá-lo. Ou seja, haveria uma episteme capaz de codificar a experiência societal moderna de maneira atenta à fluidez e dinâmica contemporâneas, conforme reivindicado pela produção científica recente?

O primeiro passo que nos parece central nesse desafio é acentuar a dimensão propriamente contingente e agonística de toda e qualquer ordem normativa. Assim entendidas, a normatividade de um dado cenário e a configuração de direitos e deveres prevalecentes passam a ser vistas como resultados instáveis de embates entre projetos distintos de sociedade, que lutam entre si para fazer valer e institucionalizar suas demandas, interesses, anseios e necessidades. Atentos às demandas do debate em torno da condição "pós-colonial", isso significa reconhecer a ampla variedade de atores que habitam o tecido societário, situados em diferentes posições (em seu "núcleo" tanto quanto em suas "margens"). Tais atores, seja nas arenas públicas ou nos âmbitos privados, buscam moldar a ordem social à sua imagem e semelhança. A prevalência de um dado projeto normativo pode, então, ser vislumbrada como contingente a uma série de fatores incapazes de serem reduzidos "em última instância" a qualquer plano invariável do social (seja econômico, cultural, geopolítico etc.) (Laclau, 1996; Laclau \& Mouffe, 2001). Se assim for, torna-se problemático atribuir a qualquer experiência societal uma única configuração de cidadania, como se ela the fosse algo essencial e impermeável a pressões por mudanças.

O segundo passo demanda uma revisão das principais referências a partir das quais o "discurso sociológico da modernidade" tem, até então, codificado o padrão de sociabilidade moderno. Consoante às ponderações do de- 
bate a respeito das "múltiplas modernidades", isso requer o reconhecimento de que existem distintas conformações de diferenciação social, ao mesmo tempo que tipos diversos de atuação da religião nas arenas públicas e privadas, além de maneiras diversas a partir das quais os âmbitos públicos e privados são definidos e circunscritos. Ademais, nos passos do que vem sendo salientado pela discussão da "pós-colonialidade", é preciso estar alerta para o equívoco de se tomar por certo a existência de diferenças estanques entre as configurações do "centro" e da "periferia". À luz, pois, de algumas reflexões da teoria sociológica contemporânea, a ideia de um "desvio da experiência da cidadania no Brasil" torna-se algo merecedor de cuidadosas reavaliações.

Abstract: This article aims at carrying out a critique of the so-called "thesis of the Brazilian normative exceptionality". The two driving questions are: first and foremost, is there any disadvantage, from an analytical point of view, in remaining oriented by the notion according to which the experience of citizenship in Brazil is something peculiar as compared to the "nucleus of modernity"? Secondly, is it possible to envisage another fruitful way of framing such an experience which goes beyond the "exceptionality thesis"? Key-words: citizenship in Brazil, brazilian social thought, modernity.

\section{Referências bibliográficas}

ApPIAH, Kwame (1992). In my father's house: Africa in the philosophy of culture, Nova York: Oxford University Press.

Araúso, Ângela (1998). A construção do consentimento: Corporativismo e trabalhadores no Brasil dos anos 30, São Paulo: Edições Sociais.

AvritZer, Leonardo (2002). "Orçamento participativo: As experiências de Porto Alegre e Belo Horizonte", in Evelina Dagnino, Sociedade civil e espaços públicos no Brasil, São Paulo: Paz e Terra.

Bendix, Reihardt (1996). Nation building and citizenship, New Bruswick: Transactions Publishers.

ВНАВнА, Homi (1998). O local da cultura, Belo Horizonte: Editora UFMG.

Boтtomore, Tom (1992). "Citizenship and social class, forty years on", in Thomas H. Marshall \& Tom Bottomore, Citizenship and social class, Londres: Pluto Press. 
Brandão, G. M. (2007). Linhagens do pensamento político brasileiro, São Paulo: Aderaldo \& Rothschild Editores.

Bruneau, Thomas (1982). The church in Brazil: The politics of religion, Austin: University of Texas Press.

Camargo, Aspásia et alii (1989). O golpe silencioso: As origens da república corporativa, Rio de Janeiro: Rio Fundo Editora.

CARdoso, Fernando H. (1972). O modelo político brasileiro, São Paulo: Difel.

Cardoso, Fernando H. \& Faletto, Enzo (1979). Dependency and development in Latin America, Berkeley: University of California Press.

CARone, Edgar (1974). A República Nova (1930-1937), São Paulo: Difel.

(1977). O Estado Novo (1937-1945), São Paulo: Difel.

Carvalho, José M. (2000). Os bestializados: O Rio de Janeiro e a república que não foi, 3. ed., São Paulo: Cia das Letras.

- (2001). Cidadania no Brasil: O longo caminho, Rio de Janeiro: Civilização Brasileira.

Casanova, José (1994). Public religions in the modern world, Chicago: The University of Chicago Press.

(2006). "Religion, European secular identities, and European integration", in T. Byrnes \& P. Katzenstein (eds), Religion in an expanding Europe, Nova York: Cambridge University Press.

CHAcon, Vamireh (2008). Formação das ciências sociais no Brasil, Brasília/São Paulo: Paralelo 15 / Editora Unesp.

Chauí, Marilena (1994). "Raízes teológicas do populismo no Brasil: Teocracia dos dominantes, messianismo dos dominados", in Evelina Dagnino, Os anos 90: Política e sociedade no Brasil, São Paulo: Brasiliense.

Cohen, Jean \& Arato, Andrew (1992). Civil society and political theory, Cambridge: The MIT Press. 
Costa, Sérgio (1994). "Esfera pública, redescoberta da sociedade civil e movimentos sociais no Brasil - Uma abordagem tentativa", Novos Estudos Cebrap, São Paulo, n. 38, pp. 38-52.

D’Araúso, Maria C. (org) (1999). As instituições brasileiras da Era Vargas, Rio de Janeiro: Eduerj/Editora da FGV.

Dagnino, Evelina (1994). "Os movimentos sociais e a emergência de uma nova noção de cidadania", in Evelina Dagnino, Os anos 90: Política e sociedade no Brasil, São Paulo: Brasiliense.

(2003). "Citizenship in Latin America: An introduction", Latin American Perspectives, 129, 30 (2), pp. 3-17.

DA MatTA, Roberto (1997). A casa \& a rua, Rio de Janeiro: Rocco.

- (1980). Carnavais, malandros e heróis: Para uma sociologia do dilema brasileiro, Rio de Janeiro: Zahar Editores.

DeCCA, Edgar (1981). 1930: o silêncio dos vencidos, São Paulo: Brasiliense.

Dinız, Eli (1978). Empresário, Estado e capitalismo no Brasil: 1930/1945, Rio de Janeiro: Paz e Terra.

(1986). "O Estado Novo: Estrutura de poder, relações de classes", in Boris Fausto (ed), O Brasil republicano: Sociedade e política (1930-1964), Vol. 3, São Paulo: Difel, pp. 77-120.

Domingues, José M. (1999). Criatividade social, subjetividade coletiva e a modernidade brasileira contemporânea, Rio de Janeiro: Contra Capa.

- (2002). Interpretando a modernidade: Imaginário e instituições, Rio de Janeiro: Editora FGV.

Duarte, Adriano L. (1999). Cidadania e exclusão: Brasil 1937-1945, Florianópolis: Editora UFSC.

EIsenstadt, Shmuel N. (2000). “Multiple modernities", Daedalus, 129 (1), pp. 1-29. 
FAORo, Raymundo (2001). Os donos do poder: Formação do patronato político brasileiro, Rio de Janeiro: Globo.

Dussel, Enrique (2005). "Europa, modernidade e eurocentrism" in Edgar Lander (org), A colonialidade do saber: Eurocentrismo e ciências sociais. Buenos Aires: Clacso Livros.

Fausto, Boris (1985). "Nota introdutória”, in Boris Fausto (org), História geral da civilização brasileira, T. III, Vol. 1, São Paulo: Difel.

— (1970). A Revolução de 1930: Historiografia e história, São Paulo: Brasiliense.

- (2001). História concisa do Brasil, São Paulo: Edusp/Imprensa Oficial do Estado.

FERnANDES, Florestan (1975). Sociedades de classes e subdesenvolvimento, Rio de Janeiro: Jorge Zahar Editores.

_ (1976). A revolução burguesa no Brasil, Rio de Janeiro: Zahar Editores.

Forjaz, Maria Cecília S. (1989). Tenentismo e forças armadas na Revolução de 30, Rio de Janeiro: Forense Universitária.

Foucault, Michel (1972). The archaeology of knowledge \& the discourse on language, Nova York: Pantheon Books.

Fraser, Nancy \& Gordon, Linda (1994). "Civil citizenship against social citizenship? On the ideology of contract-versus-charity", in B. van Steernbergen (ed), The condition of citizenship, Londres: Sage Publications.

FreYre, Gilberto (1996). Sobrados e mucambos: Introdução à história da sociedade patriarcal no Brasil - 2, Rio de Janeiro: Record.

(2000). Casa-grande \& Senzala: Introdução à história da sociedade patriarcal no Brasil - 1, Rio de Janeiro: Record.

GaOnKAR, Dilip (ed) (2000). Alternative modernities, Durham: Duke University Press. 
GIlroy, Paul (1993). The black Atlantic: Modernity and double consciousness, Londres: Verso.

Gole, Nilüfer (2000). "Snapshots of Islamic modernities". Daedalus, 129 (1), pp. 91-117.

Gomes, Ângela. C. (1979). Burguesia e trabalho: Política e legislação social no Brasil, 1917-1937, Rio de Janeiro: Campus.

- (1994). A invenção do trabalhismo, Rio de Janeiro: Relume Dumará.

- (1980). "Introdução", in idem, Regionalismo e centralização política: Partidos e constituinte nos anos 30, Rio de Janeiro: Nova Fronteira, pp. 23-39.

- (1986). "Confronto e compromisso no processo de constitucionalização (1930-1935)", in Boris Fausto (ed), História geral da civilização brasileira, Vol. 3, São Paulo: Difel, pp. 7-75.

GorJANicyn, Katrina (2000). "Citizenship and culture in contemporary France: Extreme right interventions", in A. Vanderberg (ed), Citizenship and democracy in a Global Era, Londres: MacMillan Press Ltd.

HABERMAS, Jürgen (1998). Between facts and norms, Cambridge: The MIT Press.

Holanda, Sérgio Buarque de (1994). Raízes do Brasil, Rio de Janeiro: José Olympio.

Holston, James \& Caldeira, Teresa (1998). "Democracy, law and violence: Disjunctions of Brazilian citizenship", in F. Aguero \& J. Stark (eds), Fault lines of democracy in post-transition Latin America, Florida: North-South Center Press, pp. 263-296.

Honneth, Axel (1995). The struggle for recognition, Cambridge: The MIT Press.

Huntington, Samuel (1996). The clash of civilizations and the remaking of the world order, Nova York: Simon \& Schuster.

IanNI, Octavio (1978). O colapso do populismo no Brasil, Rio de Janeiro: Civilização Brasileira. 
Katzenstein, Peter (2006). "Multiple modernities as limits to secular Europeanization?", in T. Byrnes \& P. Katzenstein (eds), Religion in an expanding Europe, Cambridge: Cambridge University Press, pp. 1-33.

LACLAU, Ernesto (1996). Emancipation(s), Londres: Verso.

LACLAU, Ernesto \& Mouffe, Chantal (2001). Hegemony and socialist strategy, Londres: Verso.

Lahuerta, Milton (1997). "Os intelectuais e os anos 20: Moderno, modernista, modernização", in E. Lorenzo \& W. Costa, A década de 1920 e as origens do Brasil moderno, São Paulo: Editora Unesp, pp. 93-104.

LAMOUnier, Bolivar (org) (1990). De Geisel a Collor: O balanço da transição, São Paulo: Sumaré/Idesp.

LANDER, Edgar (org) (2005). A colonialidade do saber: Eurocentrismo e ciências sociais, Buenos Aires: Clacso Livros.

LeAL, Victor N. (1977). Coronelismo: The municipality and representative government in Brazil, Nova York: Cambridge University Press.

Leme, Maria Saenz (1978). A ideologia dos industriais brasileiros: 1919-1945, Petrópolis: Vozes.

ManN, Michael (1996). "Ruling class strategies and citizenship", in M. Bulmer \& A. M. Rees (eds), Citizenship today: The contemporary relevance of $T$. H. Marshall, Londres, UCL Press Ltd.

Marshall, Thomas H. (1992). "Citizenship and social class", in Thomas H. Marshall \& Tom Bottomore, Citizenship and social class, Londres: Pluto Press.

MıcEl, Sérgio et alii (1987). História das ciências sociais no Brasil, Vol. 1, São Paulo: Vértice.

Mignolo, Walter (2000). "(Post)occidentalism, (post)coloniality, and (post)subaltern rationality", In Fawzia Afzal-Khan \& Kalpana Seshadi-Crooks (eds), The pre-occupation of postcolonial studies, Durham: Duke University Press, pp. 86-118. 
Moraes Filho, Evaristo (1978). O problema do sindicato único no Brasil (seus fundamentos sociológicos), São Paulo: Alfa-Ômega.

Munakata, Kazumi (1981). A legislação trabalhista no Brasil, São Paulo: Brasiliense.

NABuco, Joaquim (2000). O abolicionismo, Rio de Janeiro/São Paulo: Nova Fronteira/Publifolha.

Neves, Marcelo (1994). "Entre subintegração e sobreintegração: A cidadania inexistente", Dados: Revista de Ciências Sociais, Rio de Janeiro, 37 (2), pp. 253-276.

- (1996). "Luhmann, Habermas e o Estado de Direito", Lua Nova, n. 37, pp. 93-106.

Offe, Claus (1996). Modernity and the State: East, West, Cambridge: The MIT Press.

Paranhos, Adalberto (1998). O roubo da fala: Origens do trabalhismo no Brasil, São Paulo: Boitempo.

Parsons, Talcott (1971). The system of modern societies, Eaglewood Cliffs: Prentice-Hall.

PoGGI, Gianfranco (1978). The development of the modern state: A sociological introduction, Stanford: Stanford University Press.

Prado Jr., Caio (1994). Evolução política do Brasil: Colônia e império, 21. ed., São Paulo: Brasiliense.

— (1970). História econômica do Brasil, São Paulo: Brasiliense.

Pratt, Mary L. (1999). Os olhos do Império: Relatos de viagem e transculturação, Bauru: Edusc.

Quijano, Aníbal (2005). "Colonialidade do saber, eurocentrismo e América Latina", in Edgar Lander (org), A colonialidade do saber: Eurocentrismo e ciências sociais, Buenos Aires: Clacso Livros. 
Ramos, Guerreiro (1996). A redução sociológica, Rio de Janeiro: Editora UFRJ.

Rodrigues, Leôncio M. (1996). Conflito industrial e sindicalismo no Brasil, São Paulo: Difel.

SAES, Décio (2001). "A questão da evolução da cidadania política no Brasil", Estudos Avançados, São Paulo, 15 (42), pp. 379-410.

(1985). Classe média e sistema político no Brasil, São Paulo: T. A. Queiroz.

SAID, Edward (1979). Orientalism, Nova York: Vintage Books.

Sales, Teresa (1994). "Raízes da desigualdade social na cultura política brasileira", Revista Brasileira de Ciências Sociais. São Paulo, n. 25, pp. 26-37.

Santos, Boaventura de Souza (1997). Pela mão de Alice, São Paulo: Cortez.

Santos, Wanderley Guilherme dos (1987). Cidadania e Justiça: A política social na ordem brasileira, Rio de Janeiro: Campus.

SCHMIDT, Volker (200\&). "Múltiplas modernidades ou variedades da modernidade?", Revista de Sociologia e Política, n. 28, pp. 147-160.

Seshadri-Crooks, Kalpana \& Afzal-Khan, Fawazi (eds) (2000). The preoccupation of postcolonial studies, Durham/Londres: Duke University Press.

Seshadri-Crooks, Kalpana (2002). "At the margins of postcolonial studies: Part 1", in Fawzia Afzal-Khan \& Kalpana Seshadi-Crooks, The pre-occupation of postcolonial studies, Durham: Duke University Press, pp. 3-23.

Somers, Margaret (1993). "Citizenship and the place of the public sphere: Law, community, and political culture in the transition to democracy", American Sociological Review, Chicago, October, Vol. 58, pp. 587-620.

Souza, Jessé (2000). A modernização seletiva: Uma interpretação do dilema brasileiro, Brasília: Editora Universidade de Brasília.

- (2006). A construção social da subcidadania: Para uma sociologia política da modernidade periférica. Belo Horizonte: Editora UFMG. 
SoYSAL, Yasemin (1995). Limits of citizenship: Migrants and postnational membership in Europe, Chicago: The University of Chicago Press.

SPIVAK, Gayatri (1987). In other worlds: Essays in cultural politics, Londres: Methuen.

TAvolaro, Sergio B. F. (2005). "Existe uma modernidade brasileira? Reflexões em torno de um dilema sociológico brasileiro", Revista Brasileira de Ciências Sociais, 20 (59), pp. 5-22.

- (2008). "Quando discursos e oportunidades políticas se encontram: Para repensar a sociologia política da cidadania moderna", Novos Estudos, Cebrap, n. 81, pp. 117-136.

(2009). "Para além de uma 'cidadania à brasileira': Uma consideração crítica da produção sociológica nacional", Revista de Sociologia e Política, Vol. 17, n. 32, pp. 95-120.

Telles, Vera (1994). "Sociedade civil e a construção de espaços públicos", in Evelina Dagnino, Os anos 90: Política e sociedade no Brasil, São Paulo: Brasiliense.

TIBI, Bassam (2006). Europeanizing islam or the islamization of Europe: Political democracy vs. cultural difference", in Timothy Byrnes \& Peter Katzenstein, Religion in an expanding Europe, Nova York: Cambridge University Press.

ToRres, Alberto (1982). A organização nacional, Brasília: Editora Universidade de Brasília.

Vianna, Luiz W. (1989). Liberalismo e sindicato no Brasil, Rio de Janeiro: Paz e Terra.

Vianna, Oliveira (1956). Evolução do povo brasileiro, Rio de Janeiro: José Olympio.

(1987). Populações meridionais do Brasil, Vol. 1, Niterói: Editora UFF.

WITTRock, Björn (2000). "Modernity: One, none, or many? European origins and modernity as a global condition", Daedalus, 129 (1), pp. 31-60. 